But we finally found the bullpen just in time,

And since I'm here, I guess you could say it went OK.

You've got to remember, all this was a long time ago,

And I might do it again, but set down

This set down

This: Sorry, lost my train of thought

There: But think about

This: Do you want to go all that way

For one lousy interview?

They'll hire you certainly,

I know your CV and have no doubt.

But there are jobs, and there are Jobs.

I know being a part-time temp at your alma mater

Is hard and kind of embarrassing,

With all your old crowd gone off

And the new bunch seeming like aliens to you,

But for a position teaching five sections of comp?

Tenure-track or not, I'd rather die.

Marc D. Cyr

Georgia Southern University

\section{Deciphering the Equiano Archives}

\section{To the Editor:}

In his "The Other Interesting Narrative: Olaudah Equiano's Public Book Tour" (121 [2006]: 1424-42), John Bugg welcomes my "company in studying the book tour" Equiano took throughout England, Ireland, and Scotland between 1789 and 1794 (1438n2). To my earlier narration of the tour in Equiano, the African: Biography of a Self-Made Man (U of Georgia P, 2005), Bugg has added several letters Equiano published in newspapers during those years, as well as indications of Equiano's posthumous reception history. Bugg has clearly done some rewarding and welcome archival digging. Readers of PMLA will decide for themselves the extent to which Bugg's account of Equiano's book tour and its implications overlap with my own.

Several comments and suggestions Bugg makes in the first section of his article, however, require a response. His assertion that I "claim that Equiano was born in South Carolina" misrepresents my position (1424). In my biography I say that if the baptismal and naval records are accurate, Equiano was born in South Carolina, and not Africa. I admit that " $[\mathrm{r}]$ easonable doubt raised by the recent biographical discoveries inclines me to believe that the accounts of Africa and the Middle Passage in The Interesting Narrative were constructed-and carefully so-rather than actually experienced and that the author probably invented an African identity. But we must remember that reasonable doubt is not the same as conviction. We will probably never know the truth about the author's birth and upbringing" (xiv-xv). Similarly, citing an article I published in 2003 in which I mistakenly say that Equiano did not publicly claim an African nativity before the 1780s, Bugg ignores my more recent observation in the biography that Equiano may have first made such a claim in 1779 (197).

Bugg and I disagree about likely interpretations of evidence found in Equiano's naval records. Since the grounds for his disagreement are anticipated and addressed at length in chapter 7 of my biography, I shall treat the issues only briefly here. Citing David Waldstreicher's "Reading the Runaways: Self-Fashioning, Print Culture, and Confidence in Slavery in the Eighteenth-Century Mid-Atlantic" (William and Mary Quarterly 56 [1999]: 243-72), Bugg suggests that "Equiano may have listed an American birthplace to deflect those pursuing runaway slaves" (1425). His suggestion, however, overlooks Waldstreicher's caveat that "[a]ny effort to appreciate the nature and impact of 
unfree mobility ... needs to be specific to region and to time" (245). Evidence on the 1773 muster lists alone undermines Bugg's suggestion. Besides men from Europe and British America, the ninetyman complement of the Racehorse included at least two able seamen born in Africa: Madagascar-born Jonathan Syfax and Guinea-born Richard Yorke. Madagascar-born able seaman Joseph Brown served on the Carcass, the Racehorse's companion ship on the expedition. Neither Syfax, Yorke, nor Brown saw any reason to conceal an African birth. Why would Equiano have done so when the records indicate that he could have claimed any birthplace he wished? Why would someone wanting to conceal an enslaved past choose South Carolina, the most fully developed slave society in North America? Besides, what is the likelihood that anyone hunting runaway slaves would target royal naval vessels sailing between England and the North Pole?

Bugg suggests that the misrecordings of "Vassa" as "Feston" and "Weston" on the 1773 muster lists of the Racehorse cast doubt on the age and South Carolina place of birth recorded for him on the same lists. As unlikely as those names may seem, they are no greater misunderstandings of "Gustavus Vassa" than the "Gusta Worcester" recorded by another purser sixteen years earlier on another vessel. Foreign names were frequently misrecorded. What are the odds that the purser of the Racehorse misheard Equiano's place of birth and age so as to render them fortuitously consistent with his previous records? Bugg offers several other candidates as possible men miscalled Feston or Weston. But what are the chances that either the future soldier or criminal Bugg suggests was among the best seamen available in peacetime for a dangerous government-sponsored voyage, rather than the experienced and demonstrably multitalented VassaEquiano? If Feston-Weston was not Vassa-Equiano, who was? Or does Bugg mean to imply that Equiano fabricated his participation in the expedition?

Vincent Carretta University of Maryland, College Park

\section{Reply:}

Anyone seeking to understand the trajectory of Equiano's life is indebted to Vincent Carretta, who has laid much of the field's groundwork, not least in the meticulous research behind his Penguin editions of The Interesting Narrative. I am therefore glad that Carretta finds my archival work on Equiano to be of interest, and I am happy to join him, Paul Edwards, Nini Rodgers, and James Green in examining Equiano's book tour and its significance. I visited archives at several of the cities on Equiano's tour, and at each I found interesting, unpublished material. As Equiano's itinerary included no less than two dozen stops, I am certain that further research will continue to develop our picture of his venture, the interest it generated, and its importance to abolition history, radical politics in 1790 s Britain and Ireland, and the history of the book.

William Blake's famous verdict that "[n]othing can be more contemptible than to suppose Public RECORDS to be True" is not the most helpful motto for scholars of literary history (The Complete Poetry and Prose of William Blake, ed. David V. Erdman, rev. ed. [Berkeley: U of California $P, 1982$ ] 617), but those who work on Equiano do deal with a complex, elusive set of historical materials, and I welcome the chance to participate in a conversation about this archive and in particular about its uncertainties. (Readers might be interested in Paul E. Lovejoy's recent contribution to this discussion, "Autobiography and Memory: Gustavus Vassa, alias Olaudah Equiano, the African," Slavery and Abolition: A Journal of Slave and Post-slave Studies 27 [2006]: 317-47.) I appreciate Carretta's candid revision of some of his earlier claims and his clarification of his present position. Even so, because Carretta's original, attention-grabbing work on Equiano's birthplace is still far better known than his subsequent refinements, I think it is necessary, for now anyway, to keep stressing the instability of the evidence.

This leaves the question of how to interpret "evidence found in Equiano's naval records," on which I respectfully disagree with Carretta. I do not accept that the "Weston" listed in the Racehorse's log book is necessarily "Vassa," rather than one of the many Westons involved in the maritime industry at the time (the few I list in my article are presented as symptoms of, not solutions to, the problem). And while it may be that Jonathan Syfax and Richard Yorke did not disguise their national identities, Equiano was more adept at identity politics than the average sailor. The question of sailors' nationalities led the United States in 1798 